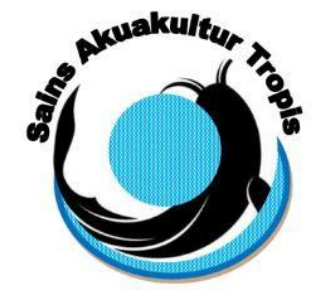

\author{
Jurnal Sains Akuakultur Tropis \\ De parte m e n $\mathrm{k} u$ a $k$ u $\mathbf{t}$ u r \\ Fakultas Perikanan dan IImu Kelautan - Universitas Diponegoro \\ Jl. Prof. Soedarto, SH, Tembalang, Semarang 50275 \\ Telp. (024) 7474698, Fax.: (024) 7474698
}

Email: sainsakuakulturtropis@gmail.com, sainsakuakulturtropis@undip.ac.id

\title{
PENGARUH CAHAYA DENGAN PANJANG GELOMBANG YANG BERBEDA TERHADAP KUALITAS WARNA IKAN BOTIA (Chromobotia macracanthus BLEEKER) DENGAN SISTEM RESIRKULASI
}

\author{
The Effect of Differences Wavelength of Light on Color Quality of Clown Loach (Chromobotia macracanthus \\ Blekeer) with Recirculation System
}

Sandhika Yoga Virgiawan, Istiyanto Samidjan, Sri Hastuti

Departemen Akuakultur, Fakultas Perikanan dan Ilmu Kelautan, Universitas Diponegoro

J1. Prof. Soedarto, SH, Tembalang, Semarang, Jawa Tengah - 50275, Telp/Fax. +6224 7474698

(email: sandhikacool@gmail.com)

\begin{abstract}
ABSTRAK
Ikan botia (C. macracanthus Bleeker) merupakan salah satu jenis ikan hias air tawar yang populer dan memiliki permintaan pasar yang tinggi. Permintaan pasar yang tinggi tidak hanya mengenai kuantitas botia, tetapi harus ditunjang dengan kualitas dari ikan botia juga. Upaya yang dapat dilakukan untuk meningkatkan kualitas botia khususnya kualitas warna ikan botia yaitu penambahan lampu LED merah. Penambahan lampu LED merah mampu meningkatkan kualitas warna merah ikan dengan low cost production, dan tidak menyebabkan ikan menjadi stres. Penelitian dilaksanakan pada bulan Juni-Juli 2019 di Laboratorium Budidaya Perairan, Universitas Diponegoro, Semarang. Tujuan penelitian ini adalah mengkaji pengaruh cahaya warna merah dan mencari panjang gelombang terbaik untuk meningkatkan kualitas warna ikan botia. Serta untuk mengetahui pengaruhnya terhadap pertumbuhan ikan botia. Ikan uji yang digunakan adalah ikan botia dengan bobot rata-rata 0,76 g, berukuran 4-5 cm. Penelitian ini menggunakan metode eksperimental dengan Rancangan Acak Lengkap yang terdiri dari 4 perlakuan dan 3 ulangan yaitu perlakuan A penambahan cahaya dengan panjang gelombang $(435 \mathrm{~nm}), \mathrm{B}(646,5 \mathrm{~nm}), \mathrm{C}(664,5 \mathrm{~nm})$, dan D $(706,1 \mathrm{~nm})$. Variabel yang diukur meliputi : tingkat stres (jumlah leukosit), kelulushidupan (SR), panjang mutlak, bobot mutlak, kualitas warna, dan kualitas air. Hasil penelitian menunjukan bahwa penambahan lampu LED warna merah memiliki pengaruh nyata $(\mathrm{P}<0,05)$ terhadap kualitas warna, panjang mutlak, dan bobot mutlak ikan botia, namun tidak memiliki pengaruh yang nyata $(\mathrm{P}>0,05)$ terhadap jumlah leukosit dan kelulushidupan $(\mathrm{SR})$. Penambahan lampu LED warna merah $(646,5$ $\mathrm{nm}$ ) dengan sistem resirkulasi berpengaruh terhadap kualitas warna dan performa pertumbuhan yang bagus pada ikan botia.
\end{abstract}

Kata Kunci : ikan botia, LED merah, kualitas warna.

\section{ABSTRACT}

C. macracanthus Bleeker is one of the popular freshwater ornamental fish species that have good demand on aquaculturist. A good demand must be asisst with quantities and quality of stock of C. macracanthus Bleeker. The solution to increase color quality of C. macracanthus Bleeker such as LED (Light-Emmiting Diode) can be applied. LED have some advance like low cost production, easy to get, and less of stress. This research was conducted in June-July 2019 at Aquaculture Laboratory. The aims of this research was to find out the wavelength of red light and to prove which one of wavelength was the best to increase the color quality and growth of $C$. macracanthus Bleeker. The fish that used for experiment were C. macracanthus Bleeker $(0.76 \mathrm{~g})$ and size 4-5 $\mathrm{cm}$. This study applied an experimental method with Compeletely Randomized Design (CRD) with 4 treatments 
and 3 replicates. The treatments of additional wavelength of LED were A (laboratory lighting $435 \mathrm{~nm}), B(646.5$ $\mathrm{nm}), C(664.5 \mathrm{~nm})$, dan $D(706.1 \mathrm{~nm})$. The measure variable are stress rate (leukocytes total), survival rate, absolute length, absolute weight, color quality, and water quality. The results showed that additional red LED lighting has significantly different $(P<0.05)$ on color quality, absolute length, and absolute weight of $C$. macracanthus Bleeker but has not signifiacntly different $(P>0.05)$ on leukocytes total and survival rate of $C$. macracanthus Bleeker. The additional of Red LED lighting $(646.5 \mathrm{~nm})$ with recirculation system has an effect dynamics of color quality and growth performance of $C$. macracanthus Bleeker.

Keywords : C. macracanthus Bleeker, red LED, color quality

\section{PENDAHULUAN}

Ikan botia (C. macracanthus Bleeker) merupakan salah satu jenis ikan hias yang populer dan memiliki permintaan pasar yang tinggi. Ikan botia atau clown loach ini tergolong ikan hias air tawar endemik yang berasal dari pulau Sumatera dan Kalimantan. Ikan ini memiliki daya tarik yaitu coraknya yang indah. Selain itu, ikan botia memiliki permintaan ekspor yang tinggi. Ini terlihat dari volume dan nilai ekspor ikan botia pada tahun 2012 mampu mencapai $29.280 \mathrm{~kg}$ dan nilai ekspor sebesar US\$ 775.384 (KKP, 2013). Peningkatan permintaan konsumen, sebaiknya diiringi dengan peningkatan produksi dan kualitas dari ikan pula. Upaya peningkatan kualitas ikan botia sebagai daya tarik keunggulannya yaitu kecerahan warna. Dari segi komersial, konsumen menganggap bahwa ikan botia yang berkualitas baik memiliki warna yang cerah, sebaliknya ikan yang berwarna pucat tidak disukai (Shahidi et al., 1998).

Rekayasa lingkungan guna meningkatkan kualitas warna ikan salah satu contohnya adalah pencahayaan. Pencahayaan memiliki karakteristik berupa panjang gelombang, intensitas dan fotoperiode (lama penyinaran) yang dapat mempengaruhi secara langsung maupun tidak langsung terhadap respons fisiologis dan pertumbuhan ikan (Karakatsouli et al., 2008). Penggunaan cahaya buatan dalam sistem budidaya dengan kombinasi panjang gelombang yang tepat menghasilkan konsentrasi pigmen pada sel kromatofor lebih tinggi, sehingga membuat warna lebih cemerlang (Tume et al., 2009). Pemberian panjang gelombang cahaya merah terhadap ikan botia menghasilkan kualitas warna yang bagus, dibandingkan dengan yang memakai cahaya ruang laboratorium (Aras, 2015). Kualitas warna pada suatu organisme akuatik dipengaruhi oleh daya absorpsi dan refleksi dari sel pigmen (Roberts dan Ellis, 2012). Gelombang cahaya warna merah berpengaruh terhadap jumlah sel kromatofor yang dihitung menggunakan metode penyapuan pada kulit ikan botia, dihasilkan sebanyak 361 sel. Sel kromatofor bertanggungjawab terhadap warna yang dihasilkan oleh suatu ikan (Aras, 2015). Salah satu penelitian rekayasa lingkungan budidaya yaitu dengan menggunakan gelombang cahaya LED merah, penelitian ini memberikan hasil terbaik pada LED merah dalam menghasilkan warna ikan yellowtail clownfish Amphiprion clarki (Shin et al., 2011).

Resirkulasi merupakan salah satu sistem budidaya yang menggunakan kembali air budidaya setelah melalui berbagai treatment. Keuntungan dari sistem ini diantaranya dapat diterapkan pada air yang terbatas, mudah dikontrol, dan memiliki fleksibelitas tinggi. Sistem resirkulasi juga dapat mempengaruhi kualitas warna yang dihasilkan oleh ikan hias. Hal ini dikarenakan, sistem resirkulasi dapat menjaga kualitas air yang diharapkan sesuai dengan kultivan. Jika kualitas air sesuai dengan kultivan, maka tingkat stres ikan hias akan rendah, dan jumlah sel kromatofor yang dihasilkan akan banyak, sehingga warna yang dihasilkan akan maksimal. Sistem resirkulasi harus memiliki filter yang berfungsi untuk memperbaiki kualitas air (Priono dan Satyani 2012). Ikan botia dapat dibudidayakan dalam akuarium bervolume 5 liter dengan sistem resirkulasi dengan tingkat kepadatan 15 ekor atau dapat diaplikasikan pada skala wadah yang lebih besar, yaitu menggunakan akuarium volume 100 liter dengan kepadatan 15 ekor/L pada ketinggian air media $32 \mathrm{~cm}$ dalam sistem resirkulasi (Priyadi et al., 2010).

Penelitian ini bertujuan untuk mengkaji bagaimana pengaruh cahaya buatan (artificial lighting) untuk pertumbuhan dan meningkatkan kualitas warna pada ikan botia. Penelitian ini dilaksanakan pada bulan Juni-Juli 2019 di Laboratorium Budidaya Perairan, Fakultas Perikanan dan Ilmu Kelautan, Universitas Diponegoro, Semarang.

\section{MATERI DAN METODE}

Alat dan Bahan

Alat yang digunakan pada penelitian ini diantaranya akuarium dengan ukuran 20x20x20 $\mathrm{cm}^{3}$, lampu LED merah, instalasi resirkulasi satu set, waring, timbangan elektrik, milimeter blok, kamera, penggaris, selang, alat tulis. Alat yang digunakan untuk perhitungan parameter diantaranya toca color finder (TCF), water quality checker (WQC), mikroskop.

Bahan uji yang digunakan adalah ikan botia yang berasal dari berasal dari Balai Penelitian dan 
Pengembangan Budidaya Ikan Hias (BPPBIH) Depok, Jawa Barat. Benih berukuran seragam yaitu 4-5 cm. Pakan uji yang digunakan adalah cacing darah dengan kandungan protein 57\%, dengan metode pemberian pakan adalah ad-satiation (Aras, 2015). Penggunaan cacing darah sebagai pakan dikarenakan ikan botia cenderung menyukai pakan cacing darah dibandingkan dengan pakan pelet. Hal ini sudah diuji coba pengadaptasian sebelum memulai penelitian.

\section{Metode Penelitian}

Metode penelitian yang digunakan adalah berupa metode eksperimen. Penelitian ini menggunakan rancangan acak lengkap (RAL). Faktor yang digunakan terdiri atas satu faktor perlakuan yaitu panjang gelombang cahaya terdiri dari 4 perlakuan diantaranya A $(435 \mathrm{~nm}), \mathrm{B}(646,5 \mathrm{~nm}), \mathrm{C}(664,5 \mathrm{~nm})$, dan D $(706,1$ $\mathrm{nm}$ ) masing-masing dengan 3 kali ulangan sehingga berjumlah 12 unit percobaan. Perlakuan didasarkan pada pengujian lampu LED menggunakan Optical Multichannel Analyzer dan sesuai dengan range panjang gelombang warna merah.

\section{Pelaksanaan Penelitian}

Penelitian ini terdiri dari tahap persiapan, tahap pengujian, pengumpulan data dan pengukuran kualitas air. Tahap persiapan meliputi pengukuran panjang ikan botia, panjang gelombang lampu LED, persiapan akuarium $\left(20 \times 20 \times 20 \mathrm{~cm}^{3}\right)$ sudah terlapisi plastik hitam, instalasi aerasi, sistem resirkulasi yang terdiri dari filter mekanik dan biologi. Tiap akuarium diberi sekat sterofoam untuk mencegah keluarnya cahaya perlakuan. Perlakuan kontrol tetap terpapar cahaya ruang. Padat tebar ikan botia adalah 2 ekor/l. Pengujian panjang gelombang cahaya dilakukan di laboratorium radiasi menggunakan alat optical multichannel analyzer (OMA).

Tahap pengujian diantaranya perlakuan gelombang cahaya yang terpapar terhadap media budidaya. Ikan uji diberi pakan cacing darah, metode pemberian pakan hingga kenyang atau ad satiation sebanyak dua kali sehari yakni pada pukul 08.00 dan 16.00 WIB. Setiap 1 minggu sekali dilakukan sampling 3 ekor / akuarium untuk diuji.

Data yang dikumpulkan diantaranya tingkat stres ikan botia yaitu dengan menghitung jumlah sel leukosit dalam darah, pertumbuhan, kualitas warna, dan kualitas air. Jumlah sel leukosit, dan kualitas warna dihitung sesudah penelitian. Kualitas warna dihitung menggunakan alat TCF (Toca Color Finder), analisa menggunakan aplikasi adobe photoshop CS5, dan perhitungan sel kromatofor dilakukan di mikroskop dengan perbesaran 100x dan 400x. Pengukuran pertumbuhan dilakukan setiap 1 minggu sekali pada saat sampling. Data pendukung yang dikumpulkan adalah pengukuran kualitas air yang direkap pada akhir penelitian.

\section{Pengumpulan Data \\ Kualitas Warna}

Pengukuran warna dilakukan pada akhir pemeliharaan menggunakan metode scoring dengan menentukan skala warna ikan uji berdasarkan standar warna TCF, pengamatan sel kromatofor dan Adobe Photoshop CS5 dibandingkan warna pada ikan uji. Penetapan standar warna dilakukan oleh 10 orang panelis untuk menghindari terjadinya bias dalam melakukan penilaian. Panelis yang dipilih adalah panelis yang tidak buta warna. Adapun penilaian warna ikan uji meliputi warna pada punggung ikan botia.

Kualitas warna benih ikan botia juga dilihat dari jumlah sel kromatofor. Penghitungan jumlah sel kromatofor dilakukakan pada akhir penelitian. Jaringan target penghitungan yaitu di lapisan dermis, bagian bawah sirip dorsal yang terlebih dahulu dijadikan preparat. Penghitungan dilakukan menggunakan mikroskop dengan lensa perbesaran 100x dan 400x (Aras, 2015).

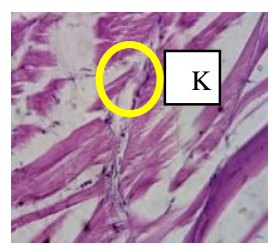

Sebelum perlakuan

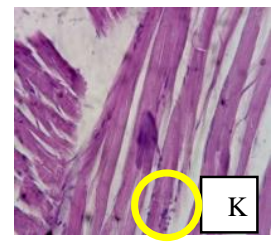

Perlakuan A $(435 \mathrm{~nm})$

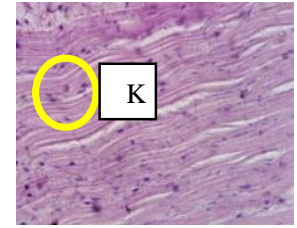

Perlakuan B $(646,5 \mathrm{~nm})$

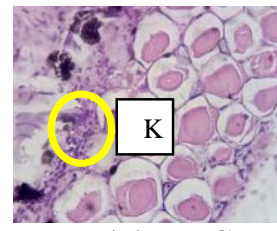

Perlakuan C $(664,5 \mathrm{~nm})$

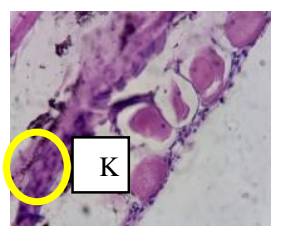

Perlakuan D

$(706,1 \mathrm{~nm})$

Keterangan : $\mathrm{K}$ = distribusi sel kromatofor

Gambar 1. Perbedaan sebaran sel kromatofor sebelum dan sesudah perlakuan

Keragaan warna diamati secara visual pada akhir penelitian dengan menggunakan kamera DSLR (Digital Single-Lens Reflex). Kemudian dianalisa dengan metode konversi gradasi warna menurut skala dan persentase 
menggunakan aplikasi Adobe Photoshop CS5. Keragaan warna yang diamati adalah skala hue. Pengamatan dilakukan terhadap punggung ikan botia dengan 3 kali ulangan per perlakuan.

Tingkat kelulushidupan merupakan hasil dari persentase ikan yang hidup dibanding jumlah total ikan pada awal tebar per perlakuan. Panjang mutlak dihitung berdasarkan selisih panjang rata-rata akhir (Pt) dengan panjang rata-rata awal $(\mathrm{Po})$ pemeliharaan. Bobot mutlak dihitung berdasarkan selisih bobot rata-rata akhir $(\mathrm{Wt})$ dengan bobot rata-rata awal (Wo) pemeliharaan. Tingkat stres ikan botia selama penelitian ditinjau melalui jumlah leukosit dalam darah ikan botia. Hal ini diperkuat Hartika et al. (2014) bahwa jumlah leukosit pada ikan normal berkisar antara 20.000-150.000 sel per $\mathrm{mm}^{3}$ darah. Variabel kualitas air yang diukur diantaranya : suhu, DO, dan pH. Pengukuran kualitas air dilakukan setiap hari

Analisis data meliputi tingkat stres ikan botia, panjang mutlak, bobot mutlak, jumlah sel kromatofor, analisa nilai "hue" dilakukan uji statistik parametrik menggunakan Analisis Sidik Ragam (ANOVA) dengan aplikasi Microsoft Excel dan diuji lanjut dengan uji Tukey dengan selang kepercayaan 95\%. Sedangkan pengamatan kualitas warna metode alat TCF dianalisis dilakukan uji statistik menggunakan uji Kruskal-Wallis dengan program SPSS 24 dengan selang kepercayan 95\%. Data kualitas air dan Tingkat Kelulushidupan dianalisis secara deskriptif.

\section{HASIL DAN PEMBAHASAN}

HASIL

1. Kualitas warna ikan botia

a. toca color finder (TCF)

Tabel 1. Skoring Warna pada Sirip Punggung Ikan Botia (C. Macracanthus Bleeker) pada Akhir Penelitian.

\begin{tabular}{cc}
\hline Perlakuan & Skoring Warna \\
\hline A $435 \mathrm{~nm}$ & $2(7), 3(3)$ \\
B $646,5 \mathrm{~nm}$ & $2(2), 3(3), 4(5)$ \\
C $664,5 \mathrm{~nm}$ & $2(2), 3(5), 4(3)$ \\
D $706,1 \mathrm{~nm}$ & $2(6), 3(3), 4(1)$ \\
\hline
\end{tabular}

Keterangan : A : (Kontrol) cahaya ruang (435 nm); B : LED merah (646,5 nm); C : LED merah (664,5 nm); D : LED merah $(706,1 \mathrm{~nm})$.

Berdasarkan tabel skoring warna pada punggung (dorsal) ikan botia data skoring warna diubah menjadi rangking menggunakan uji kruskal-wallis sehingga penyajian data supaya lebih mudah dipahami. Tabel rangking disajikan pada Tabel 2.

Tabel 2. Rangking Warna pada Sirip Punggung Ikan Botia (C. Macracanthus Bleeker) pada Akhir Penelitian.

\begin{tabular}{cc}
\hline Perlakuan & Rangking Warna \\
\hline A $435 \mathrm{~nm}$ & 13,65 \\
B 646,5 nm & 27,15 \\
C 664,5 nm & 24,85 \\
D 706,1 nm & 16,35 \\
\hline
\end{tabular}

Keterangan : A : (Kontrol) cahaya ruang (435 nm); B : LED merah (646,5 nm); C : LED merah (664,5 nm); D : LED merah $(706,1 \mathrm{~nm})$.

Berdasarkan Tabel 2 warna pada bagian dorsal memilik rata-rata skoring warna yang terbaik diperoleh pada perlakuan B sebesar 27,15 diantara perlakuan yang lain. Perlakuan gelombang cahaya LED warna merah memberikan pengaruh yang nyata terhadap skoring warna punggung ikan botia $(\mathrm{P}<0,05, \mathrm{P}=0,013)$.

\section{b. sel kromatofor}

Berdasarkan perhitungan jumlah sel kromatofor nilai rata-rata sel kromatofor pada punggung ikan botia masing-masing perlakuan tertinggi pada perlakuan B dengan perlakuan cahaya 646,5 nm diperoleh sebesar

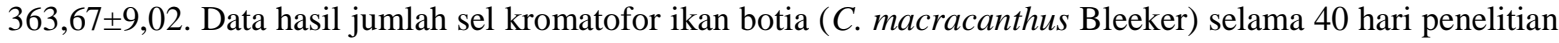
juga dapat dibuat grafik seperti pada Gambar 2. 


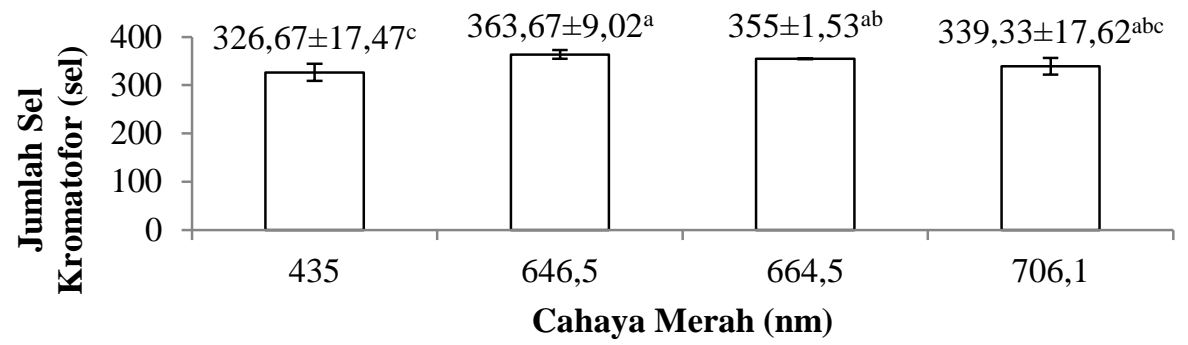

Gambar 2. Grafik Perhitungan Jumlah Sel Kromatofor Ikan Botia (C. macracanthus Bleeker) Selama 40 Hari Penelitian

\section{c. analisa visual}

Berdasarkan perhitungan hue ikan botia (C. macracanthus Bleeker) masing-masing perlakuan tertinggi pada perlakuan B dengan perlakuan cahaya $646,5 \mathrm{~nm}$ diperoleh sebesar $29,33 \pm 0,58$. Data hasil perhitungan derajat hue ikan botia selama 40 hari penelitian juga dapat dibuat grafik seperti pada Gambar 3 .

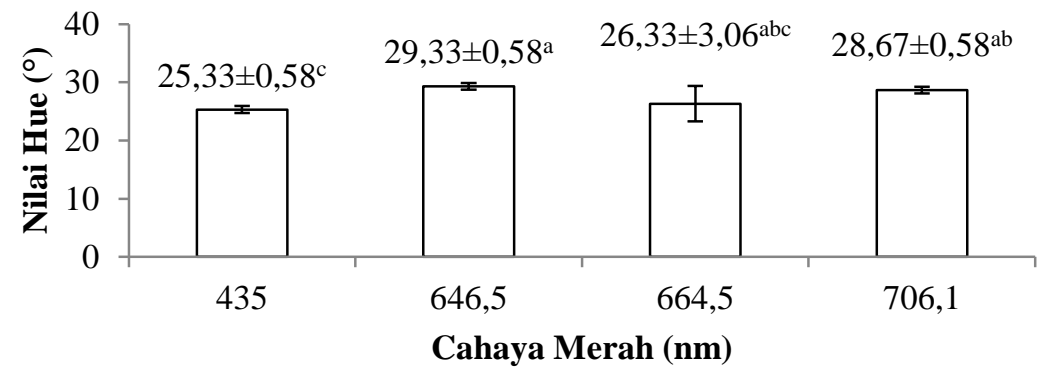

Gambar 3. Grafik Perhitungan Nilai Hue Ikan Botia (C. macracanthus Bleeker) pada Adobe Photoshop Selama 40 Hari Penelitian

\section{Tingkat kelulushidupan}

Berdasarkan perhitungan sintasan ikan botia didapatkan hasil bahwa rata-rata sintasan tertinggi berada pada perlakuan A $(435 \mathrm{~nm})$ dan D $(706,1 \mathrm{~nm})$ dengan nilai rata-rata sebesar $100 \%$, kemudian perlakuan C $(664,5$ $\mathrm{nm})$ dan B $(646,5 \mathrm{~nm})$ dengan rata-rata $94,44 \%$. Data hasil tingkat kelulushidupan ikan botia selama 40 hari penelitian juga dapat dibuat grafik seperti pada Gambar 4.

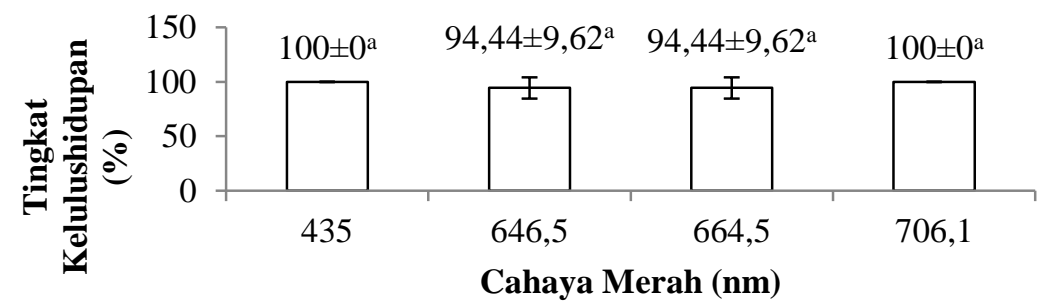

Gambar 4. Grafik Tingkat Kelulushidupan Ikan Botia (C. macracanthus Bleeker) Selama 40 Hari Penelitian.

\section{Panjang mutlak}

Berdasarkan pengukuran panjang mutlak didapatkan hasil bahwa rata-rata panjang mutlak tertinggi berada pada perlakuan B sebesar 1,22 $\pm 0,06 \mathrm{~cm}$, perlakuan $\mathrm{C}$ sebesar $1,19 \pm 0,03 \mathrm{~cm}$, perlakuan D sebesar

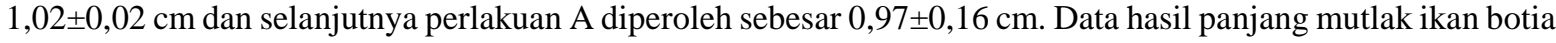
(C. macracanthus Bleeker) selama 40 hari penelitian juga dapat dibuat grafik seperti pada Gambar 5. 


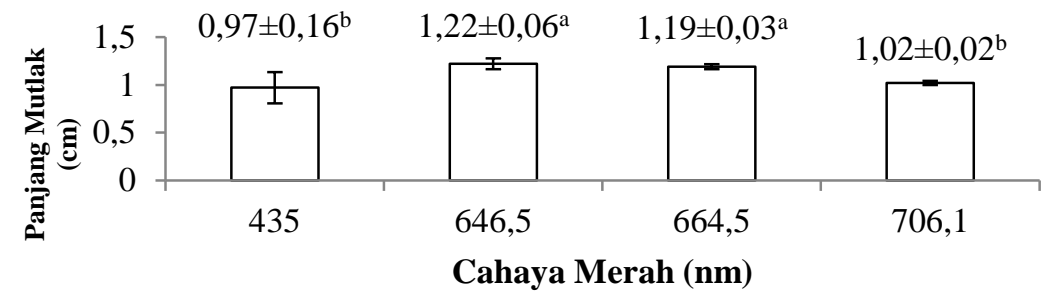

Gambar 5. Grafik Pertumbuhan Panjang Mutlak Ikan Botia (C. macracanthusBleeker) Selama 40 Hari Penelitian.

\section{Bobot mutlak}

Berdasarkan tabel perhitungan bobot mutlak nilai rata-rata bobot mutlak ikan botia masing-masing perlakuan tertinggi pada perlakuan B dengan perlakuan cahaya 646,5 nm diperoleh sebesar 0,43 $\pm 0,05$ gram. Data hasil bobot mutlak ikan botia (C. macracanthus Bleeker) selama 40 hari penelitian juga dapat dibuat grafik seperti pada Gambar 6.

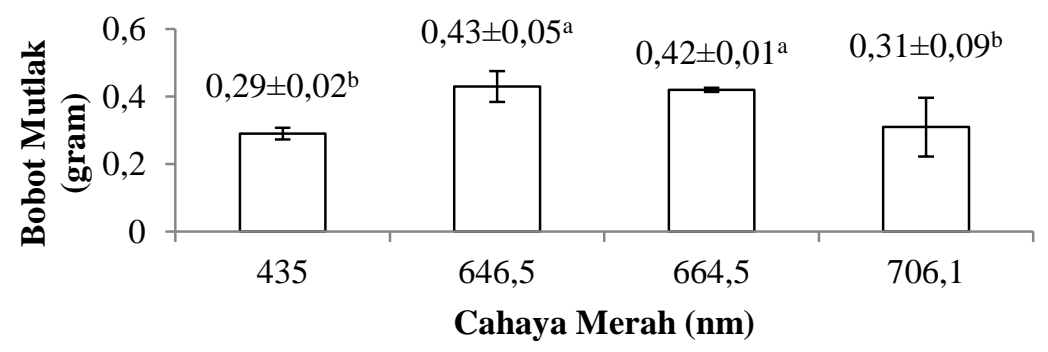

Gambar 6. Grafik Pertumbuhan Bobot Mutlak Ikan Botia (C. macracanthus Bleeker) Selama 40 Hari Penelitian.

\section{Tingkat stres ikan botia}

Jumlah leukosit ikan botia didapatkan hasil bahwa rata-rata jumlah leukosit tertinggi berada pada perlakuan $C$ dengan nilai rata-rata $2,37 \pm 0,03 \times 10^{4} \mathrm{sel} / \mathrm{mm}^{3}$, kemudian perlakuan A dengan nilai rata-rata $2,23 \pm 0,2 \times 10^{4} \mathrm{sel} / \mathrm{mm}^{3}$, perlakuan B dengan nilai rata-rata $2,13 \pm 0,06 \times 10^{4} \mathrm{sel} / \mathrm{mm}^{3}$ dan D dengan nilai rata-rata selisih sebesar $2,12 \pm 0,03 \times 10^{4} \mathrm{sel} / \mathrm{mm}^{3}$. Data hasil jumlah leukosit pada ikan botia selama 40 hari penelitian juga tersaji pada Gambar 7.

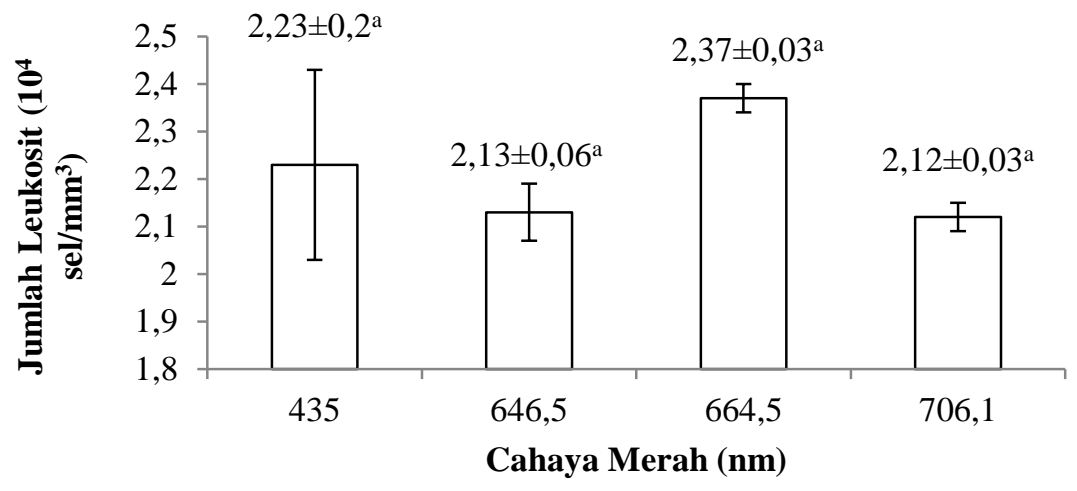

Gambar 7. Grafik Rata-Rata Jumlah Leukosit Ikan Botia (C. macracanthus Bleeker) Selama 40 Hari Penelitian

\section{Kualitas air}

Pengukuran kualitas air diantaranya suhu, pH, dan Dissolved Oxygen (DO). Pengukuran variabel kualitas air dilakukan setiap 2 kali sehari pada waktu pagi dan sore hari. Hasil pengukuran kualitas air selama penelitian dapat dilihat pada Tabel 3. 
Tabel 3. Hasil Pengukuran Kualitas Air pada Ikan Botia (C. macracanthus Bleeker) Selama 40 Hari Penelitian

\begin{tabular}{ccccc}
\hline No & Variabel & Satuan & Hasil & Kelayakan \\
\hline 1 & Suhu & ${ }^{0} \mathrm{C}$ & $25-30$ & $24-30^{*}$ \\
2 & DO & $\mathrm{mg} / \mathrm{l}$ & $2,9-4,0$ & $2,85-8,36^{* *}$ \\
3 & $\mathrm{pH}$ & - & $6,9-7,2$ & $5,5-7,5^{* * *}$ \\
\hline
\end{tabular}

Keterangan = Satyani et al.$(2010)(*)$

Aras (2011) $(* *)$

Priyadi et al. (2010) $(* * *)$

\section{PEMBAHASAN}

\section{Kualitas warna}

Berdasarkan perhitungan skoring menggunakan alat TCF didapatkan hasil warna pada bagian dorsal memilik rata-rata skoring warna yang terbaik diperoleh pada perlakuan B sebesar 27,15 diantara perlakuan yang lain. Peningkatan kualitas warna pada ikan botia dengan penambahan LED merah dengan panjang gelombang cahaya yang berbeda, mampu mempengaruhi distribusi sel kromatofor. Semakin banyak dan menyebar sel kromatofor, warna yang dihasilkan juga semakin baik. Hal ini diperkuat Robert dan Ellis (2012) bahwa kualitas warna dapat dipengaruhi daya absorbsi dan refleksi dari sel pigmen. Menurut Elsbaay (2013) bahwa adaptasi layaknya habitat asli kultivan budidaya, warna cahaya berpengaruh terhadap deteksi ikan pada pakan, sehingga berdampak pada pertumbuhan dan mortalitas.

Berdasarkan perhitungan sel kromatofor pada ikan botia (C. macracanthus Bleeker) didapatkan hasil

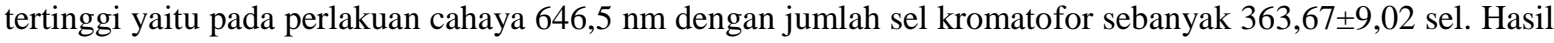
tersebut lebih baik daripada penelitian Aras (2015) bahwa kualitas warna yang dihasilkan ikan botia dengan pemaparan warna merah $(550-750 \mathrm{~nm})$ dengan penghitungan kromatofor dengan metode penyapuan dihasilkan sebesar 361 sel. Hal ini diperkuat pernyataan dari Leclerq et al. (2010) bahwa dalam fisiologi perubahan warna pada ikan teleostei, salah satu faktor yang mempengaruhi distribusi kromatofor adalah cahaya buatan (artificial lighting).

Berdasarkan perhitungan terhadap derajat hue pada ikan botia (C. macracanthus Bleeker) pada aplikasi Adobe Photoshop CS5, didapatkan hasil bahwa perlakuan B dengan panjang gelombang cahaya 646,5 nm

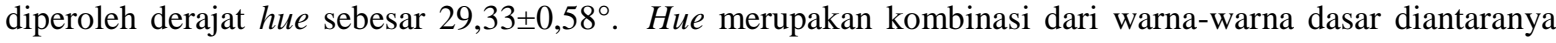
merah, hijau, biru pada adobe photoshop sehingga perhitungan hue dapat mewakilkan ekspresi warna dari ikan uji. Hal ini sesuai dengan penelitian dari Yasir dan Qin (2009) bahwa pada clownfish (Amphiprion ocellaris) yang memiliki warna oranye-kemerahan memiliki derajat hue berkisar $25-41^{\circ}$. Hal ini diperkuat oleh Chapman dan Miles (2018) bahwa pigmen warna pada organisme akuatik dapat bertanggung jawab terhadap nilai hue.

\section{Tingkat Kelulushidupan (Survival Rate)}

Berdasarkan penelitian penambahan gelombang cahaya dengan frekuensi berbeda yang telah dilakukan selama 40 hari dihasilkan bahwa sintasan selama penelitian berturut-turut adalah sebagai berikut: perlakuan A dan D dengan nilai rata-rata sebesar $100 \%$, kemudian perlakuan B dan perlakuan C dengan rata-rata 94,44\%. Nilai sintasan yang dihasilkan selama penelitian tidak berbeda signifikan. Kematian botia selama penelitian diduga disebabkan oleh sisa pakan dan feses yang bersedimentasi dibawah akuarium, sehingga kualitas air terganggu. Hal ini diperkuat oleh Lesmana dan Daelami (2009) yang menyatakan bahwa bahan yang tidak bermanfaat dan bahkan merugikan bagi kultivan biasanya tersedimentasikan didasar perairan. Solusi yang tepat yaitu membuangnya dengan cara menyipon. Tingkat kematian selama penelitian masih berkisar diatas $80 \%$. Hal ini dapat diartikan bubidaya tersebut baik. Sintasan dapat juga dipengaruhi oleh daya dukung lingkungan suatu perairan dapat memenuhi kebutuhan tiap-tiap populasi serta kebutuhan ikan botia akan pakan terpenuhi. Menurut Teguh (2008) yang menyatakan bahwa kelulushidupan bagi ikan budidaya dapat dikatakan baik apabila jumlah ikan hidup mencapai 80-90\%.

\section{Panjang mutlak}

Berdasarkan penelitian penambahan panjang gelombang cahaya dengan frekuensi berbeda yang telah dilakukan selama 40 hari, didapatkan hasil bahwa uji analisa ragam yaitu berpengaruh nyata $(\mathrm{P}<0,05)$ terhadap pertumbuhan panjang mutlak ikan botia. Pertumbuhan panjang tertinggi selama penelitian terdapat pada perlakuan B sebesar 1,22 $\pm 0.06 \mathrm{~cm}$. Hal ini dapat terjadi diduga botia yang digunakan untuk penelitian masih benih dengan ukuran 3-4 cm. Ikan yang masih berukuran muda lebih cepat pertumbuhannya dibandingkan dengan ikan yang dewasa. Ikan muda energi yang didapatkan dari makanan bisa diakumulasikan terhadap pertumbuhan ikan tersebut. Hal ini diperkuat oleh Payuk et al. (2016) yang menyatakan ikan yang berumur muda 
lebih cepat pertumbuhannya dari pada ikan yang sudah berumur tua. Hal ini disebabkan karena energi yang didapatkan dari makanan tidak digunakan sepenuhnya untuk pertumbuhan, melainkan untuk mengganti sel-sel tubuh yang rusak dan untuk proses reproduksi.

Faktor eksternal seperti kualitas air yang sesuai untuk ikan uji mampu menunjang pertumbuhannya. Sistem resirkulasi yang diterapkan diduga mampu mengoptimalkan kualitas air dalam sistem sehingga sesuai dengan kultivan. Hal ini diperkuat oleh Rochmatin et al. (2014) bahwa kecepatan pertumbuhan panjang dan berat ikan dapat dipengaruhi oleh faktor internal dan eksternal. Faktor internal antara lain keturunan dan jenis kelamin yang membawa sifat genetik masing-masing dari alam yang sulit untuk dikontrol. Faktor eksternal antara lain yaitu lingkungan seperti suhu, salinitas dan makanan yang dikonsumsi oleh ikan.

\section{Bobot mutlak}

Berdasarkan tabel perhitungan bobot mutlak nilai rata-rata bobot mutlak ikan botia (C. macracanthus Bleeker) perlakuan tertinggi pada perlakuan B dengan panjang gelombang cahaya 600-650 nm diperoleh sebesar $0,43 \pm 0,05$ gram. Pengujian analisa sidik ragam (ANOVA) didapatkan hasil bahwa pemberian panjang gelombang cahaya yang berbeda yaitu berpengaruh nyata $(\mathrm{P}<0,05)$ terhadap pertumbuhan bobot mutlak ikan botia. hal ini diduga karena pada dasarnya habitat asli ikan botia adalah perairan yang redup, sehingga botia dapat dengan mudah menemukan dan memakan cacing darah. Hal ini diperkuat oleh Aras (2015) yang menyatakan bahwa ikan botia yang habitat alaminya di sungai lebih menyukai perairan yang redup yakni suka berlindung dibawah akar pohon. Ikan botia diduga telah beradaptasi dengan gelombang cahaya warna merah sehingga memudahkan melihat serta memakan cacing darah.

Faktor yang mempengaruhi pada bobot ikan botia diantaranya respon ikan botia terhadap pakan cacing darah yang diberikan. Ikan botia cenderung aktif ketika diberi pakan cacing darah, disamping cacing darah yang tinggi akan protein hewani sehingga pertumbuhan panjang dan bobot berbanding lurus dengan respon pakan. Hal ini diperkuat oleh Kusmini et al. (2016) bahwa perbedaan perubahan bobot mutlak dipengaruhi juga oleh alokasi energi untuk tumbuh dan reproduksi, pakan yang dikonsumsi, timbunan lemak yang bisa menyebabkan bobot ikan berbeda walaupun panjangnya sama. Hal ini juga diperkuat oleh Ekavianti (2004) yang menyatakan bahwa ikan botia merupakan ikan karnivora yang membutuhkan kadar protein lebih tinggi. Ikan botia cenderung menyukai pakan cacing darah dibanding dengan pelet.

\section{Tingkat stres ikan botia}

Berdasarkan tabel perhitungan jumlah leukosit ikan botia didapatkan hasil bahwa rata-rata jumlah leukosit tertinggi berada pada perlakuan C dengan nilai rata-rata 2,37 $\pm 0,03 \times 10^{4} \mathrm{sel} / \mathrm{mm}^{3}$, kemudian perlakuan A dengan nilai rata-rata $2,23 \pm 0,2 \times 10^{4} \mathrm{sel} / \mathrm{mm}^{3}$, perlakuan B dengan nilai rata-rata $2,13 \pm 0,06 \times 10^{4} \mathrm{sel} / \mathrm{mm}^{3}$ dan D dengan nilai rata-rata selisih sebesar $2,12 \pm 0,03 \times 10^{4} \mathrm{sel} / \mathrm{mm}^{3}$. Tingkat stres ikan botia selama penelitian ditinjau melalui jumlah leukosit dalam darah ikan botia. Hal ini bertujuan untuk mengetahui apakah perlakuan tersebut berpengaruh terhadap tingkat stres ikan botia yang ditinjau dari jumlah leukosit. Hal ini diperkuat oleh Yuni et al. (2019) yang menyatakan bahwa jumlah leukosit yang tidak normal dan mengalami lonjakan, maka dapat diduga kultivan tersebut mengalami stres. Hal ini diperkuat Hartika et al. (2014) bahwa jumlah leukosit pada ikan normal berkisar antara 20.000-150.000 sel per $\mathrm{mm}^{3}$ darah. Hal ini juga diperkuat oleh Fazio et.al, (2015) bahwa jumlah sel darah putih pada ikan kakap dengan perlakuan cahaya matahari lebih lama tidak berbeda signifikan daripada budidaya kakap didalam ruangan. Sel darah putih menunjukan bahwa ikan tersebut dalam kondisi stres.

Perhitungan jumlah leukosit dalam darah ikan botia selama penelitian terdapat peningkatan jumlah leukosit tidak terlalu signifikan. Hal ini diperkuat oleh Hastuti (2004) yang menyatakan bahwa jumlah total leukosit dalam darah dapat menunjukan status kesehatan ikan. Ikan yang mengalami stres yang disebabkan oleh perubahan kondisi lingkungan memperlihatkan respons kenaikan jumlah sel leukosit. Menurut Anderson dan Siwicki (1993) dalam Syawal et al. (2008) yang menyatakan bahwa peningkatan jumlah leukosit dapat dijadikan tanda adanya infestasi faktor parasit dan stres. Hal ini juga diperkuat oleh Pearce (1989) yang menyatakan bahwa faktor-faktor yang mempengaruhi jumlah leukosit diantaranya spesies, kondisi pakan, kandungan bahan organik dalam tubuh, lingkungan, dan tingkat stres pada ikan.

\section{Kualitas air}

Hasil pengukuran kualitas air pada variabel suhu, $\mathrm{pH}$, dan oksigen terlarut berturut-turut adalah $25-30^{\circ} \mathrm{C}$, 6,9-7,2, dan 2,9 - 4,0 mg/l. berdasarkan hasil tersebut, diketahui bahwa kualitas air selama penelitian masih dalam kisaran normal sehinggga menunjang kelangsungan hidup dan pertumbuhan ikan botia. Konsentrasi oksigen terlarut yang optimal untuk ikan botia berkisar antara 2,85-8,36 mg/, kisaran pH yang baik untuk ikan botia adalah 5,5-7,5, dan kisaran suhu yang normal 24-30 ${ }^{\circ} \mathrm{C}$ (Priyadi et al,. 2010; Satyani et al., 2010; Aras, 2011) 


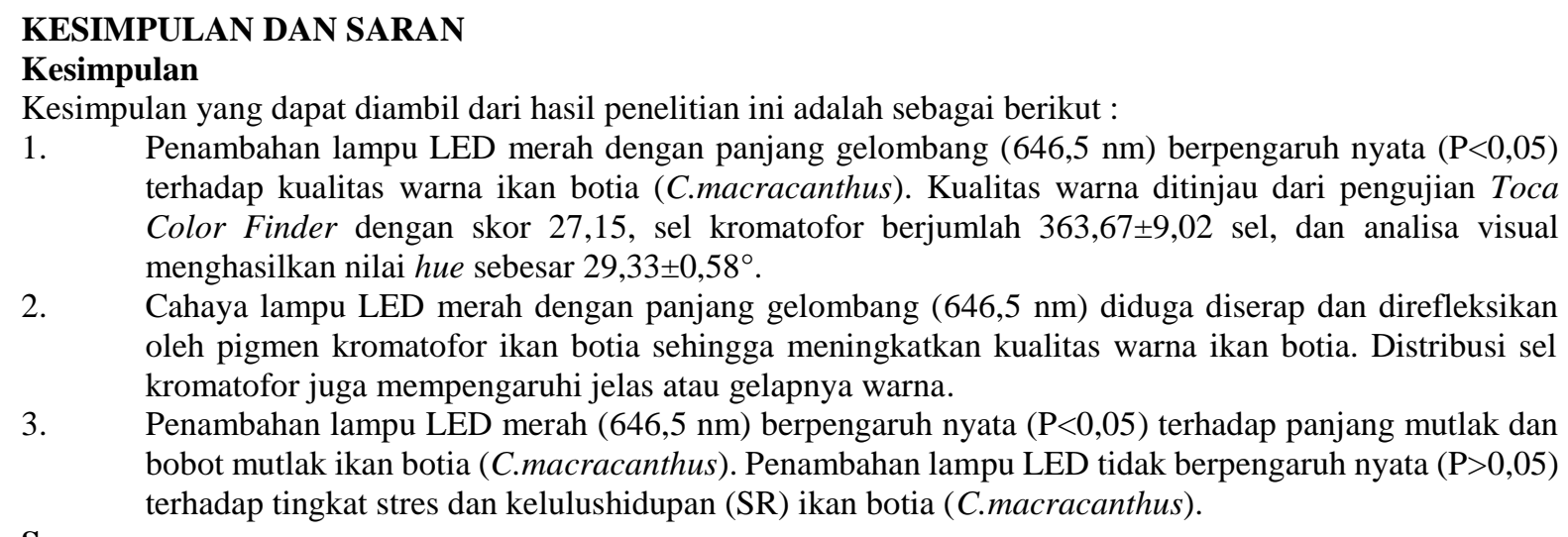

Saran yang dapat diberikan dari penelitian ini yaitu disarankan penelitian lanjut tentang pengaruh perbedaan intensitas penyinaran terhadap kualitas warna ikan hias dengan panjang gelombang cahaya merah 646,5 nm.

\section{DAFTAR PUSTAKA}

Aras, A.K. 2011. Penggunaan Paparan Medan Listrik 10 Volt dan Salinitas 3 ppt Terhadap Kinerja Produksi Ikan Botia Chromobotia macracanthus Bleeker dengan Kepadatan yang Berbeda. [SKRIPSI]. Bogor (ID) : Institut Pertanian Bogor.

Aras, A.K. 2015. Manipulasi Spektrum Cahaya terhadap Pertumbuhan dan Kualitas Warna Ikan Botia Chromobotia Macracanthus Bleeker [TESIS]. Bogor (ID): Institut Pertanian Bogor.

Chapman, F.A., dan R. D. Miles. 2018. How Ornamental Fishes Get Their Color. UF IFAS Extension. University of Florida : 1-6.

Effendie, M.I. 1979. Metode Biologi Perikanan. Bogor (ID):Yayasan Dewi Sri.

Ekavianti. R. 2004. Laju Pertumbuhan Benih Ikan Botia (Chromobotia macracanthus Bleeker) yang dipelihara Dalam Sistem Resirkulasi Dengan Frekuensi Pemberian Pakan yang Berbeda. Program Studi Teknologi dan Manajemen Akuakultur. Fakultas Perikanan dan Ilmu Kelautan. Institut Pertanian Bogor. Bogor. $64 \mathrm{Hlm}$.

Elsbaay, A. M. 2013. Effects of Photoperiod and Different Artifical Light Color on Nile Tilapia. Journal of Agriculture and Veterinary Science. 3(3): 5-12.

Fazio, F., V. Ferrantelli., G. Vortino., F. Arfuso., G. Giangrosso., dan C. Faggio. 2015. The Influence of Acute Handling Stress on Some Blood Parameters in Cultured Sea Bream (Sparus Aurata Linnaeus,1758). Italian Journal of Food Safety. (4): 4174-4176.

Goddard, S. 1996. Feed Management in Intensive Aquaculture. New York (US): Chapman and Hall. p 194.

Hartika, R., Mustahal.,dan A.N. Putra. 2014. Gambaran Darah Ikan Nila (Oreochromis niloticus) dengan Penambahan Dosis Prebiotik yang Berbeda dalam Pakan. Jurnal Perikanan dan Kelautan. 4(4): 259267.

Hastuti, S. 2004. Respons Fisiologis ikan gurami (Osphronemus gouramy) yang diberi pakan mengandung kromium-ragi terhadap perubahan suhu lingkungan.DISERTASI.Program Pasca Sarjana. Institut Pertanian Bogor. Bogor.

Karakatsouli, N., Papoutsoglou, S.E, Pizzania G, Tsatsos G, Tsopelakos A, Stella C, Kalogiannis D, Dalla C, Polissidis A, Papadopoulou-Daifoti Z. 2007. Effects of Light Spectrum on Growth and Physiological Status of Gilthead Seabream Sparus aurata and Rainbow Trout Oncorhynchus mykiss Reared Under Recirculating System Conditions. Aquacultural Engineering. 36: 302-309.

KKP [Kementerian Kelautan dan Perikanan]. 2013. Statistik Ekspor Hasil Perikanan Menurut Komoditi, Provinsi dan Pelabuhan Asal Ekspor 2012. Jakarta (ID): KKP Pres. p 14.

Koepke,J.A.,O.W.V.Assendelft.,L.J.Brindza.,B.H.Davis.,B.J.Fernandes.,A.S.Gewirtz., $\quad$ dan $\quad$ A. Rabinovich.2016. Reference Leukocyte (WBC) Differential Count (Proportional) and Evaluation of Instrumental Methods; Approved Standard-Second Edition.H20-A2.27(4): 63p.

Kusmini, I.I., Putri, F.P., dan Prakoso, V.A. 2016. Bioreproduksi dan Hubungan Panjang Bobot Terhadap Fekunditas pada Ikan Lalawak (Barbonymus balleroides). Jurnal Riset Akuakultur. 11(4): 339-345.

Leclercq, E., J.F. Taylor., dan H. Migaud. 2010. Morphological Skin Colour Changes in Teleosts. Fish and Fisheries. (11): 159-193. 
Lesmana,,D.S., dan D. Daelami. 2009. Panduan Lengkap Ikan Hias Air Tawar Populer. Jakarta.

Payuk, M.T., M. Mustakim., dan A. Rafi'i.2016. Analisis Pertumbuhan Beberapa Jenis Ikan di Lingkungan Perairan Danau Semayang Kabupaten Kutai Kartanegara. Jurnal Ilmu Perikanan Tropis. 22(1): 47-55.

Pearce, A. L. 1989. Dasar-dasar Biokimia. Jakarta: Erlangga.

Priyadi, A., Ginanjar, R., Permana, A., Slembrouck, J. 2010. Tingkat Densitas Larva Botia (Chromobotia macracanthus) dalam Satuan Volume Air pada Akuarium Sistem Resirkulasi. Prosiding Forum Inovasi Teknologi Akuakultur. 439-446.

Priono, B., dan D. Satyani. 2012. Penggunaan Berbagai Jenis Filter untuk Pemeliharaan Ikan Hias Air Tawar di Akuarium. Media Akuakultur 7(2) : 76-84.

Rochmatin. S.Y., A. Solichin., dan S.W.Saputra. 2014. Aspek Pertumbuhan dan Reproduksi Ikan Nilem (Ostechilus hasseli) di Perairan Rawa Pening Kecamatan Tuntang Kabupaten Semarang. E-Journal-S1 Undip. 3(3): 153-159.

Roberts, R.J, dan Ellis, A.E. 2012. Fish Pathology 4th ed: The Anatomy and Physiology of Teleosts. Roberts RJ, editor. Oxford (GB): Blackwell Publishing Ltd. p 17-20.

Satyani,.D..Nina,.M., dan Lili.S. 2010. Gambaran Pertumbuhan Panjang Benih Ikan Botia (Chromobotia macracanthus) Hasil Budidaya pada Pemeliharaan dalam Sistem Hapa dengan Padat Penebaran 5 Ekor Per Liter. Prosiding Forum Inovasi dan Teknologi Akuakultur : 395-402.

Shahidi. F, Metusalach, A., dan Brown, J.A. 1998. Carotenoid Pigments in Sea Foods and Aquaculture. Crit Rev Food Sci Nutr. 38:1-6.

Shin, H.S, Lee, J.,dan Choi, C.Y. 2011. Effects of LED Light Spectra on Oxidative Stress and The Protective Role of Melatonin in Relation to The Daily Rhythm of The Yellowtail Clownfish, Amphiprion clarkii. Comparative Biochemistry and Physiology, Part A.160: 221-228.

Syawal., H. Syafriadiman., dan S. Hidayah. 2008. Pemberian Ekstrak kayu siwak (salvadora persica L) Untuk meningkatkan kekebalan ikan mas (Cyprinus carpio L) yang dipelihara dalam keramba. Jurusan Budidaya Perairan, Fakultas Perikanan dan Ilmu Kelautan. Universitas Riau (UNRI), Pekanbaru.45-48.

Teguh, W. 2008. Pengaruh suhu yang berbeda terhadp kelulushidupan dan pertumbuhan larva ikan botia (Chromobotia macracanthus). SKRIPSI. Jurusan Perikanan. Fakultas Perikanan dan Ilmu Kelautan. Universitas Diponegoro. Semarang. 77 Hlm.

Tume, R.K., Sikes, A.L., Tabrett, S., dan Smith, D.M. 2009. Effect of Background Colour on the Distribution of Astaxanthin in Black Tiger Prawn (Penaeus monodon): Effective Method for Improvement of Cooked Colour. Aquaculture. 296: 129-135.

Yasir, I dan J.G. Qin. 2009. Effect of Light Intensity on Color Performance of False Clownfish, Amphiprion ocellaris Cuvier. Journal of The World Aquaculture Society. 40 (3): 337-351.

Yuni, K,P., H. Hasan., dan E. Prasetio. 2019. Studi Hematologi Ikan Semah (Tor Douronensis), Jelawat (Leptobarbus Hoeveni), Tengadak (Barbonymus Schwanenfeldi), Biawan (HelostomaTemminicki), dan Botia (Chromobotia Macracanthus). Jurnal Ruaya 7(1): 65-69. 